\title{
Implications of Philately in the Representation of the Ceahlău National Park from Romania - An Ecological Revised Case Study
}

\author{
Bogdan-Vasile Cioruța ${ }^{1 *}$, Alexandru Leonard Pop ${ }^{1}$ and Mirela Coman ${ }^{2,3}$ \\ ${ }^{1}$ Technical University of Cluj-Napoca -North University Center of Baia Mare, Office of Informatics, \\ 62A Victor Babeș street, 430083, Baia Mare, Romania. \\ ${ }^{2}$ Technical University of Cluj-Napoca - North University Centre of Baia Mare, Faculty of Engineering, \\ 62 A Victor Babeș street, 430083, Baia Mare, Romania. \\ 3 University of Agricultural Sciences and Veterinary Medicine in Cluj-Napoca, Faculty of Agriculture, \\ 3-5 Calea Mănăștur, 400372, Cluj-Napoca, Romania.
}

Authors' contributions

This work was carried out in collaboration among all authors. Authors BVC and ALP designed the study, performed the literature searches, andwrote the first draft of the manuscript. Author MC managed the analyses ofthe entire study. All authors read and approved the final manuscript.

Article Information

DOI: 10.9734/AJGR/2021/v4i230129 Editor(s):

(1) Dr. Xu Chong, China Earthquake Administration, China.

(2) Dr. Huan Yu, Chengdu University of Technology, China. Reviewers:

(1) Lucinete Miranda Gomes, Federal University of Amazonas, Brazil. (2) Madhab Chandra Behera, Orissa University Of Agriculture and Technology, India. (3) Kazi Moriom Jahan, Shahjalal University of Science and Technology, Bangladesh. (4) Farah Bani Affan, Koya University, Iraq. (5) Haimanot Reta, Debre Markos University, Ethiopia. Complete Peer review History: http://www.sdiarticle4.com/review-history/67983

Original Research Article

Received 02 March 2021

Accepted 11 May 2021

Published 14 May 2021

\begin{abstract}
Romania is a blessed place with many areas of unique beauty - as part of the natural heritage - with places where the spectacle of nature delights your eyes and take your breath with every step. Constantly promoting philatelic themes that use natural wealth and the beauty of our country as subjects, the administrative entity (with various names over time) responsible for issuing postage stamps performs a series of postage stamps in whose images are found rarities of flora and fauna, a miracle of nature. To show that protected natural areas have a special beauty, and to make them known to everyone, we bring to the talk the most significant philatelic peculiarities in the Ceahlău
\end{abstract}


National Park (Romania). In this context, the purpose of the research is to identify, index, analyze,
describe and disseminate the main philatelic materials that promote the protected area considered.
The realization of the whole approach was based on the information provided by a series of
philatelic catalogs and sites with dedicated philatelic content. The results show that the concern for
the habitat of the area was remarkable, both the multitude of identified philatelic pieces and their
artwork speak for themselves.

Keywords: Biodiversity; Ceahlău massif; natural heritage; national park; philatelic issues.

\section{INTRODUCTION}

Natural heritage, from a conceptual and philosophical point of view [1], is what we define and accept as being the ensemble of components and physical-geographic structures of whose importance has an economical, scientific, biogenetic, recreative, cultural and ecological significance [2]. All these roles are consider under the aspect of conserving the biodiversity, of ecosystems' functional integrity (protected areas offer a wide range of services) [3-4], genetical heritage conservation, vegetation and animals, the satisfaction of the everyday life, for both present and future generations.

Romania is a blessed place with many areas of unique beauty - as part of the natural heritage with places where the spectacle of nature delights your eyes and takes your breath away at every step [5-6]. Moreover, from a biogeographic point of view, and due to its position halfway between the North Pole and the Equator, our country possesses a high biodiversity, expressed in protected areas - more of them illustrated by philatelic materials.

As such, the present study complements the series dedicated to the implications of thematic philately in the promotion of protected areas, respectively Ceahlău National Park (a first version appearing in [5]), "Pețea Creek" Natural Reservation [6], Cozia National Park [7], Domogled - Cerna Valley National Park [8], and Rodna Mountains National Park [9].

All these studies, from an ecological-philatelic perspective are based on basic publications targeting protected areas [10], and philatelic catalogs [11-13], providing the pedoclimatic and hydrological conditions necessary for preserving the specific biological diversity, as shown by stamps [14-15], and First Day Cover in Fig. 1 [16-20].

At national level, there are about 52 ecoregions [10], with a variety of terrestrial and aquatic ecosystems see Fig. 2 [21-23]. They are specific to the coastal and seaside areas of the Black Sea, steppe, silvosteps, hills, mountains, lakes, water courses and meadows, drought areas or wetlands, including those specific to the Danube Delta, Ceahlău National Park, Retezat National Park, Rodna National Park and so on.

Constantly promoting philately themes that use the natural beauty of our country as a subjects, Romfilatelia performs a series of postage stamps in whose images are found rarities of flora and fauna, especially from the natural protected areas [21].

To show that protected natural areas have a special beauty, and also to show the implications of thematic philately in the promotion of protected areas in the country and abroad, in this paper, we bring to the discussion the most significant philatelic peculiarities (stamps, FDCs, illustrated and semi-illustrated postcard, maximum postcards) related to the Ceahlău National Park.

\section{MATERIALS AND METHODS}

The documentation for this paper started from the authors' concerns for ecological education and environmental protection, and not least because they love the idea of a harmoniously developed community with care for protected areas [1],[2]. Having at hand a series of extremely relevant studies at the national level, in terms of the management of protected areas [2428], and the philatelic issues published in catalogs [11]-[13], the authors decided to extrapolate that approaches on the Ceahlău National Park ecosystem.

The subject of the study, in the form of a philatelic circuit of Ceahlău National Park, is based on the sites that host philatelic content such as Colnect $^{\circledR}$ platform (the example illustrated in Fig. 3), Delcampe ${ }^{\circledR}$, PicClick $^{\circledR}$, StampWorld ${ }^{\circledR}$, etc., which come in addition to discussion forums and online meetings with other collectors and passionate philatelists. 


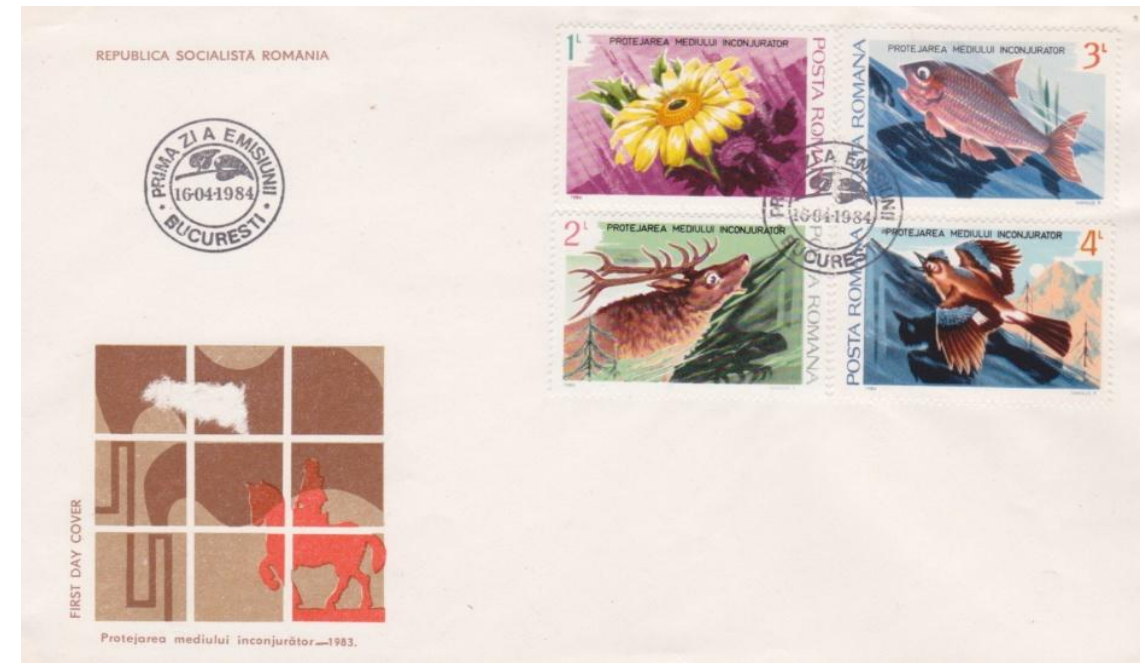

Fig. 1. "Environment protection" - a philatelic representation for Romania's high biodiversity, 16.04.1984, Bucharest (Romania) [16]-[20]

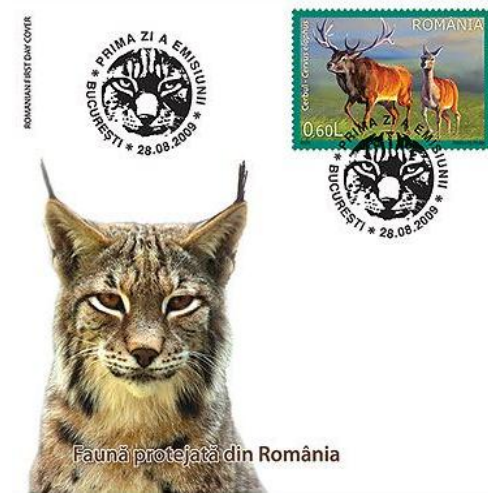

(a)

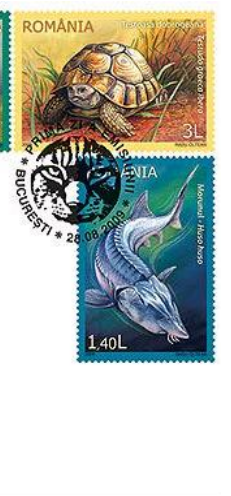

(b)

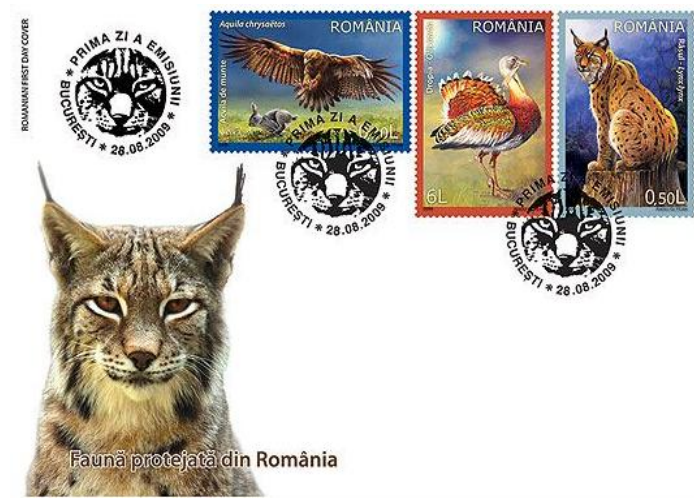

Fig. 2. "Protected fauna from Romania" - stamps representing terrestrial and aquatic ecosystems, 28.08.2009, Bucharest (Romania) [21]

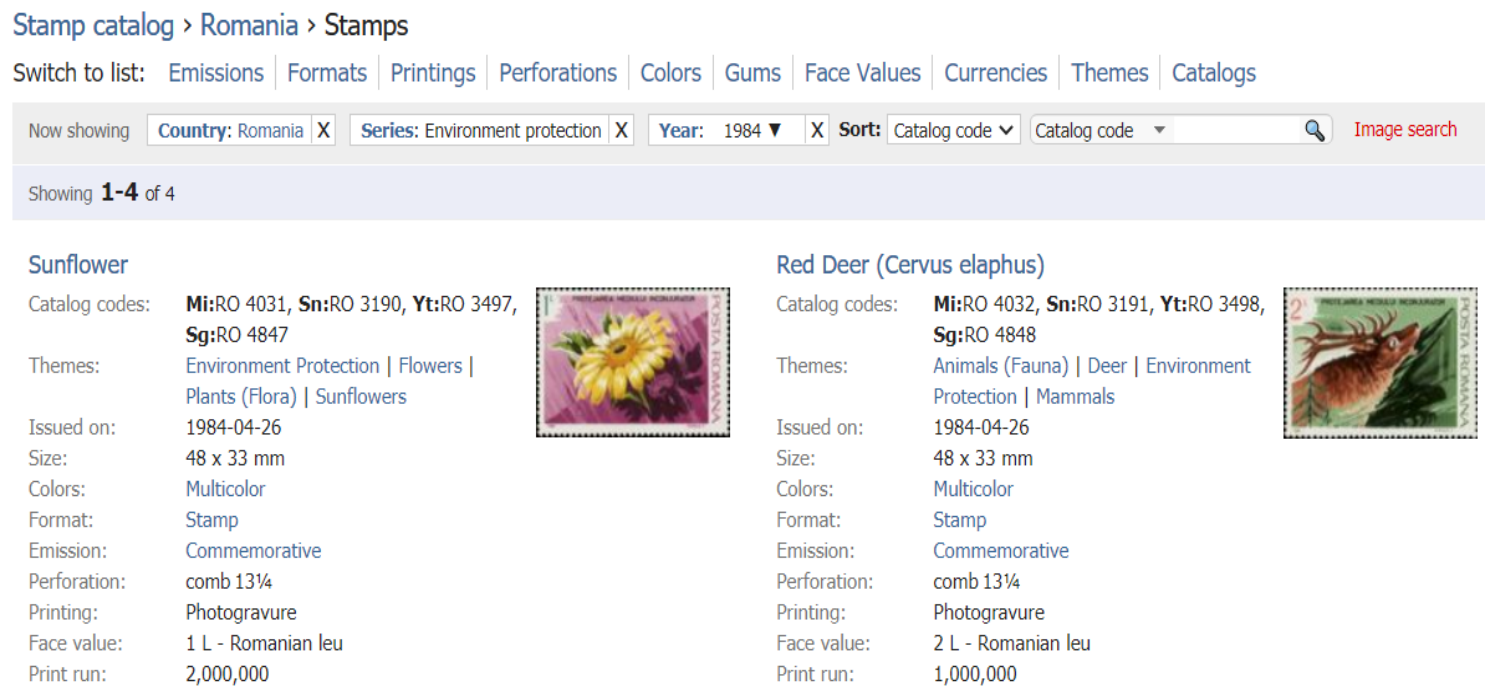

Fig. 3. Biodiversity-based stamps research within the Colnect ${ }^{\circledR}$ platform [14] 


\section{RESULTS AND DISCUSSION}

\subsection{Ceahlău National Park from an Ecological Perspective}

Ceahlău National Park is a protected area of national interest that corresponds to the second category IUCN. The natural area extends in the central-western extremity of Neamt county - as shown in Fig. 4, on the administrative territories of Bicazu Ardelean, Ceahlău and Tașca communes and of Bicaz, near the national road $12 \mathrm{C}$ that connects Piatra Neamt with Gheorgheni [29].

Ceahlau National Park was declared a protected area by Law no. 5 of 5 March 2000 on the approval of the national spatial planning plan section III - protected areas, and represents a mountainous area with a great relief diversity (towers, needles, limestone ridges, karst relief with sharp peaks, caves, gorges, valleys) with forests and meadows.The natural area has several types of habitats [29]- alluvial forests with Alnus glutinosa and Fraxinus excelsior, Dacian beech forests, acidophilous forests of Picea abies in the mountain region, forests of Larix decidua and/or Pinus cembra in the mountain region, debris and ravines, shrubs with Pinus mugo and Rhododendron myrtifolium, alpine and subalpine calcareous meadows, closed caves for public access, hedge communities with high hygrophilous grasses from the plains to the mountains and alps, rocky slopes with chasmophytic vegetation and woody vegetation along the mountain rivers that shelter a diverse flora and fauna specific to the Carpathian chain. The natural park overlaps the Natura 2000 Ceahlău site [29], based on the designation of several faunal and floristic species listed in Annex la of European Council Directive 92/43/EC of 21 May 1992 on the conservation of natural habitats and of wild fauna and flora wild. The fauna of the park is diverse and well represented by several species, among which we mention the following [23]:

mammals: deer (Cervus elaphus), roe (Capreolus capreolus), chamois (Rupicapra rupicapra), wild cat (Felis silvestris), wild boar (Sus scrofa), fox (Vulpes vulpes), marten (Martes martes), woodpecker (Meles meles), ferret (Mustela putorius), eared bat (Plecotus auritus);

$>$ birds: pigeon hawk (Accipiter gentilis), mountain eagle (Aquila chrysaetos), blue gull (Alcedo atthis), mountain eagle (Anthus spinoletta), mountain rooster (Tetrao urogallus), crow (Corvus corax), water blackbird (Cinclus cinclus), stone blackbird (Monticola saxatilis), woodpecker (Pycoides tridactylus), spotted tit (Parus cristatus), woodpecker (Lullula arborea), peregrine falcon (Falco peregrinus), collared blackbird (Turdus torquatus);

$>$ reptiles and amphibians: coronella (Coronella austriaca), field lizard (Lacerta agilis), water snake (Natrix tessellata), blind snake (Anguis fragilis), viper (Vipera berus), green toad (Bufo viridis) mountain frog (Rana temporaria), toad (Bufo bufo) or mountain newt (Triturus alpestris).

The flora of the park consists of trees and shrubs [29], with fir species (Abies alba), larch (Larix decidua), lime (Pinus cembra), yew (Taxus baccata), Scots pine (Pinus sylvestris), juniper (Juniperus sibirica and Juniperus communis), beech (Fagus sylvatica), oak (Quercus petraea and Quercus robur), hornbeam (Carpinus betulus), maple (Acer pseudoplatanus and Acer platanoides), linden (Tilia cordata), birch (Betula pendula), wicker (Salix bicolor), mountain alder (Alnus viridis), black alder (Alnus glutinosa), hazelnut (Corylus avellana), hawthorn (Crataegus monogyna), black sock (Sambucus nigra), raspberry (Robus idaeus), and rosehip (Rosa canina).

The grassy vegetation consists of different species [29], such as arnica (Arnica montana), wormwood (Artemisia eriantha), mousetail (Achillea oxyloba), omag (Aconitum napellus), mountain sandpiper (Asperula carpatica), bellflower (Campanula patula), hornbeam (Cerastium transsilvanicum), cow's breast (Primula elatior), etc.

\subsection{Ceahlău National Park from Carto- philatelic Perspective}

Mount Ceahlau is the most famous and impressive massif of the Eastern Carpathians, being one of the few Carpathian complexes that still preserves unaltered samples of nature. In addition, Ceahlău is one of the richest mountains in legend and mythology - Baba Dochia, Trajan's Eagle, Panaghia, Toaca and many others, as shown in Fig. 5 [30-38] and Fig. 6 [39-47].

The Ceahlău National Park was chosen as the theme of the most recent Romfilatelia project due to its unique character [48-50]. "Love Nature! 
Ceahlău National Park" comes to complete the series of stamp broadcasts promoting national heritage, being available from 1 September
2016, in form of FDCs Fig. 7 [48],[51] and maxicards Fig. 8 [52].

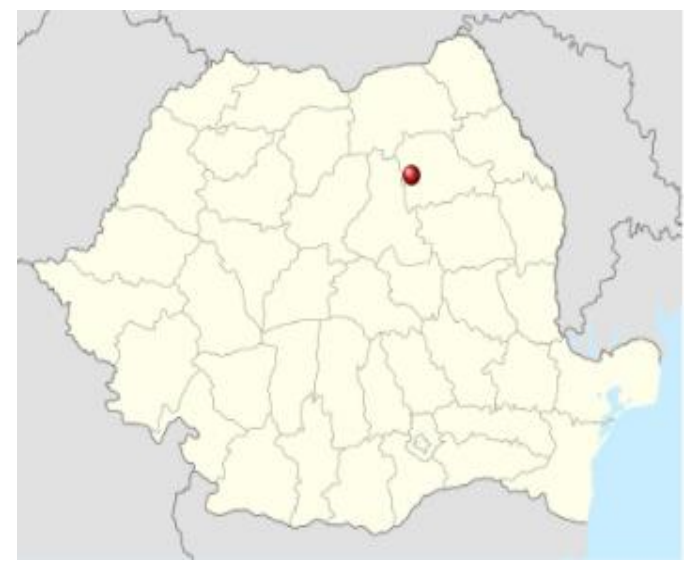

(a) positioning in relation to the map of Romania

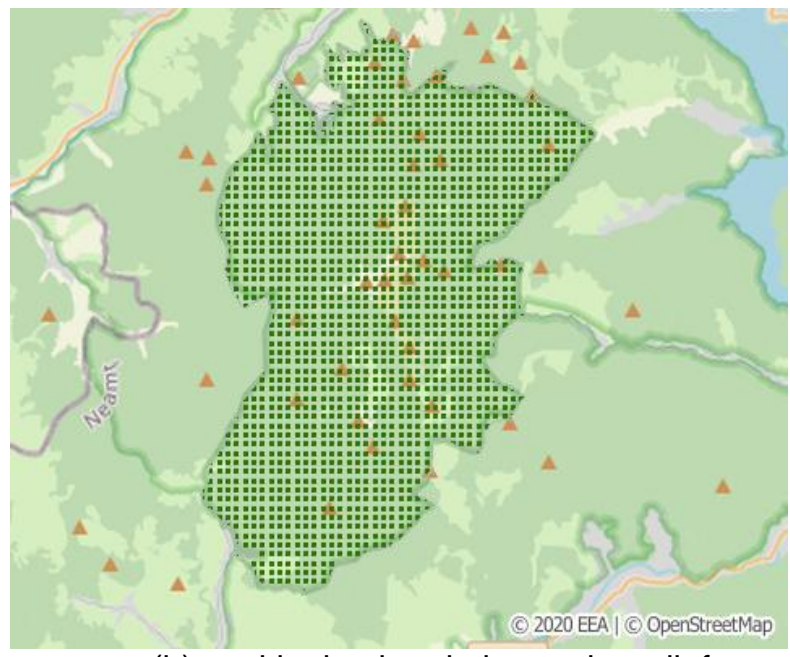

(b) positioning in relation to the relief

Fig. 4. The reference area of the ceahlău National Park (Romania)

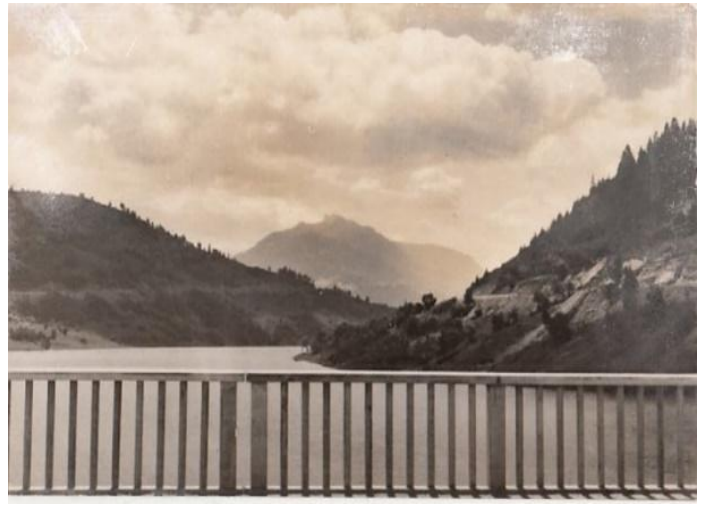

(a) Ceahlău massif seen from the Poiana Teiului bridge

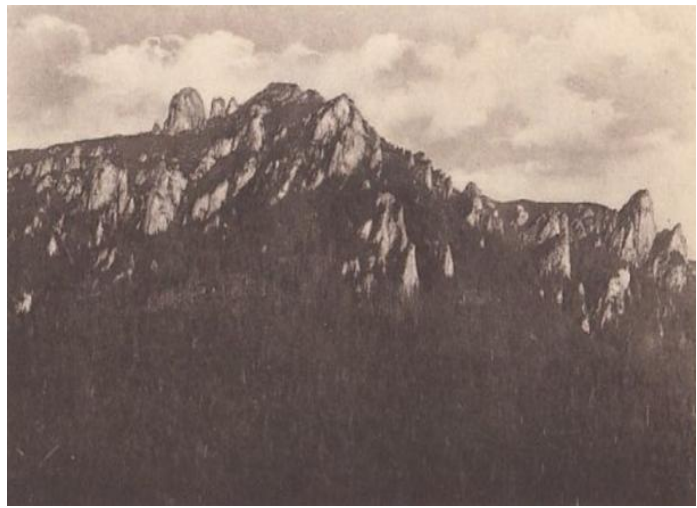

(c) General view of Ceahlău mountain

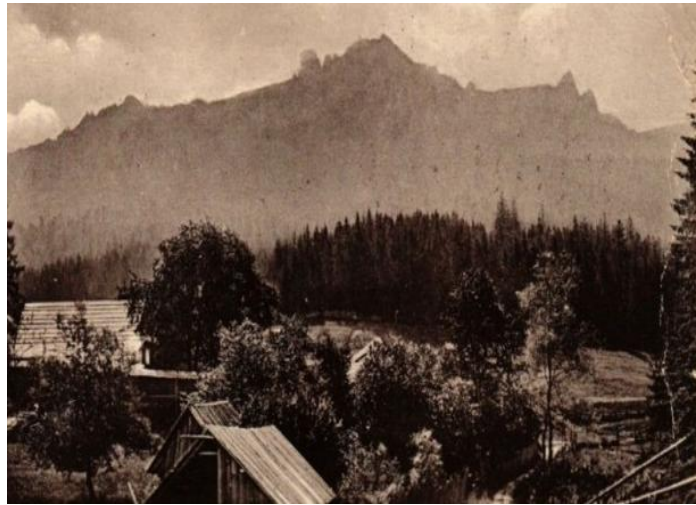

(b) View of Ceahlău mountain from Neamț county

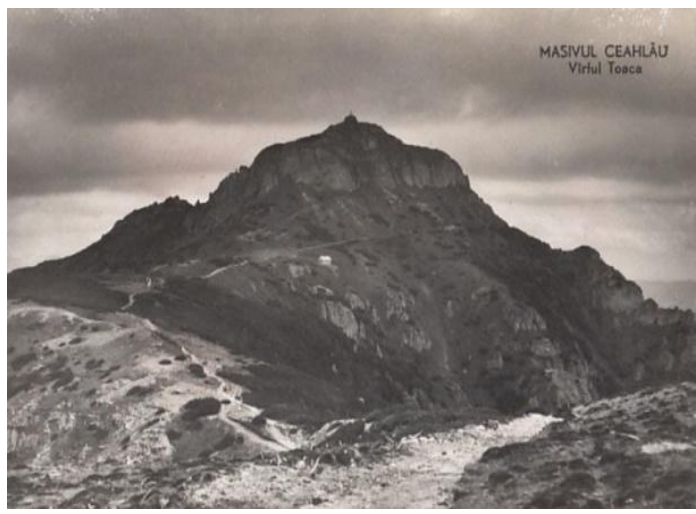

(d) Ceahlău massif with Toaca peak 


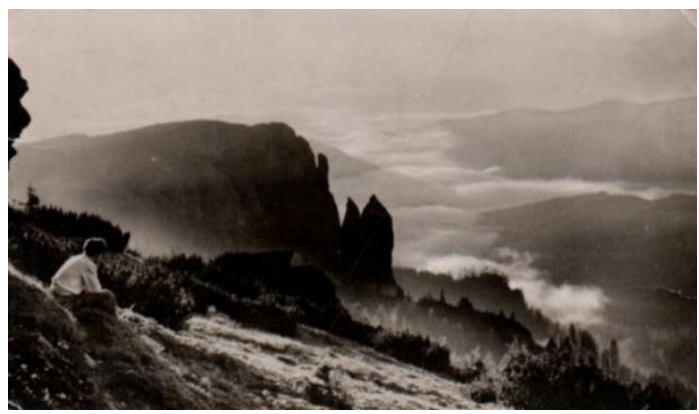

(e) General view of Ceahlău mountain

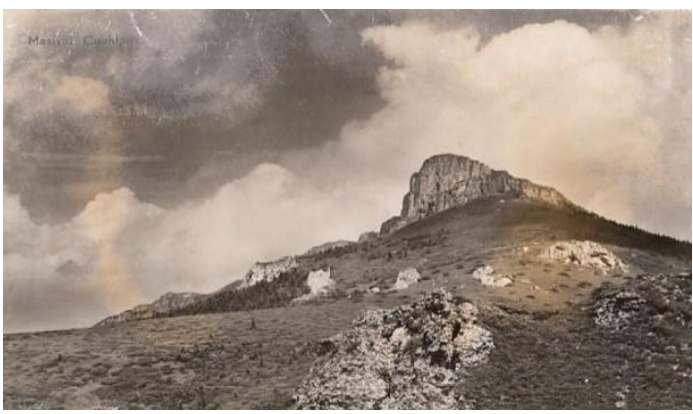

(f) Ceahlău massif with Detunata peak

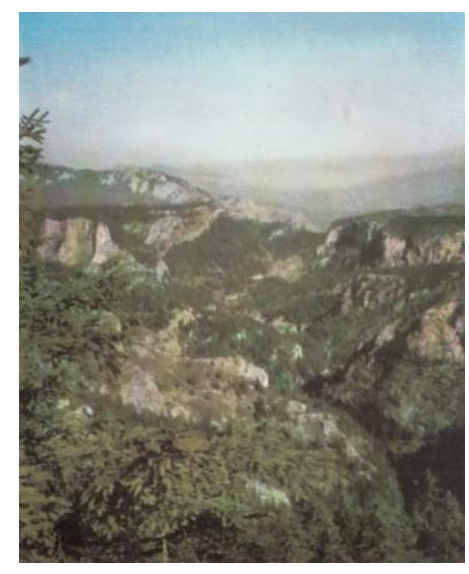

(g) General view of Ceahlău mountain

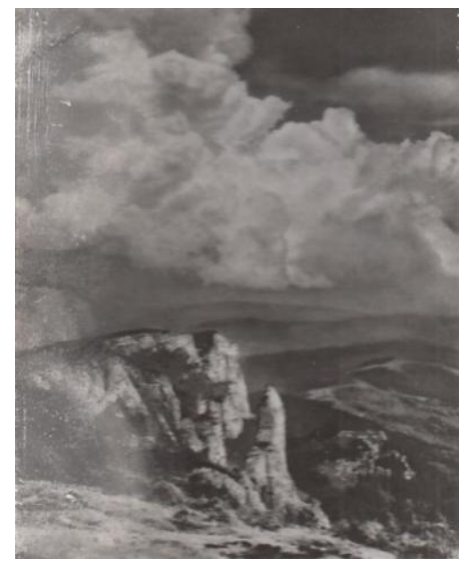

(h) General view of Ceahlău mountain

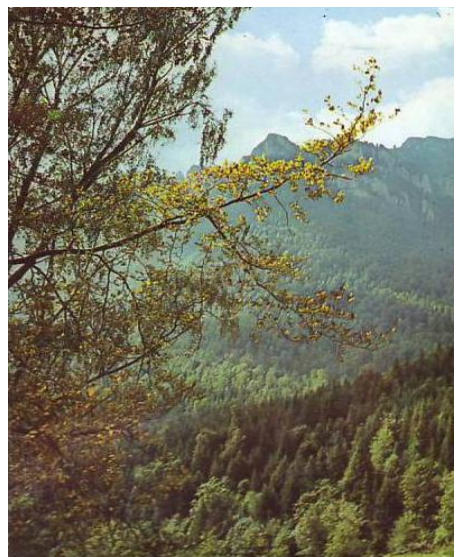

(i) General view of Ceahlău mountain

Fig. 5. Illustrated postcards showing views from the ceahlău National Park [30]-[38]

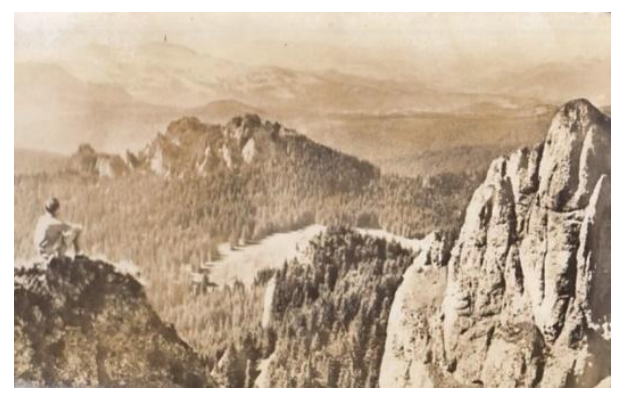

(a) Ceahlău massif with Piatra Sură peak

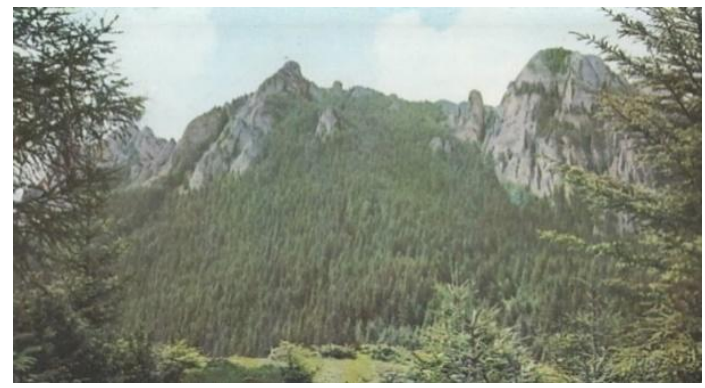

(c) Ceahlău massif panorama

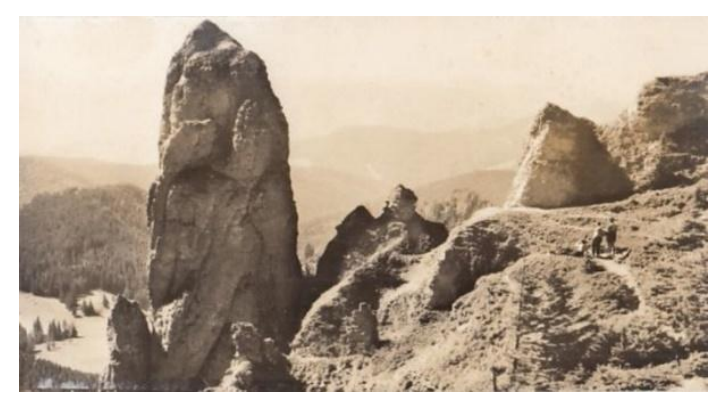

(b) Ceahlău massif with mountain rocks

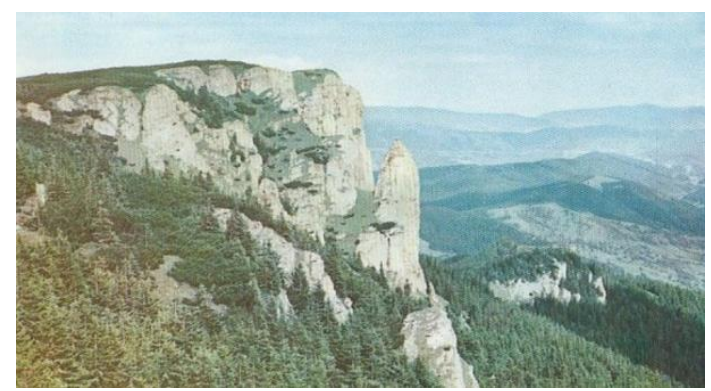

(d) Ceahlău massif with Toaca peak 


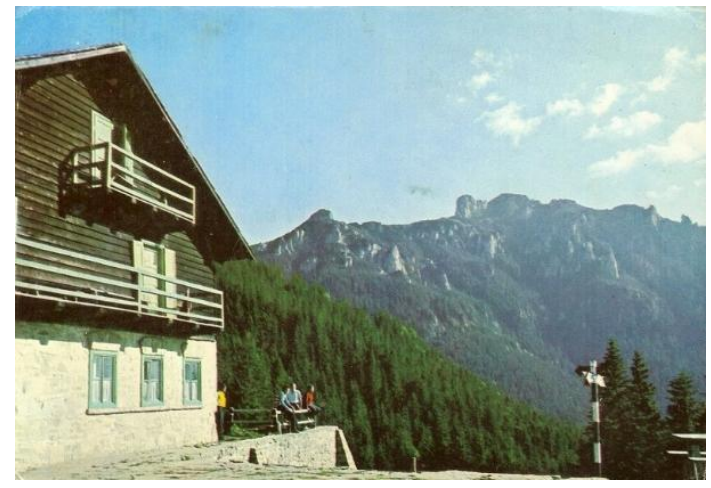

(e) Ceahlău massif panorama

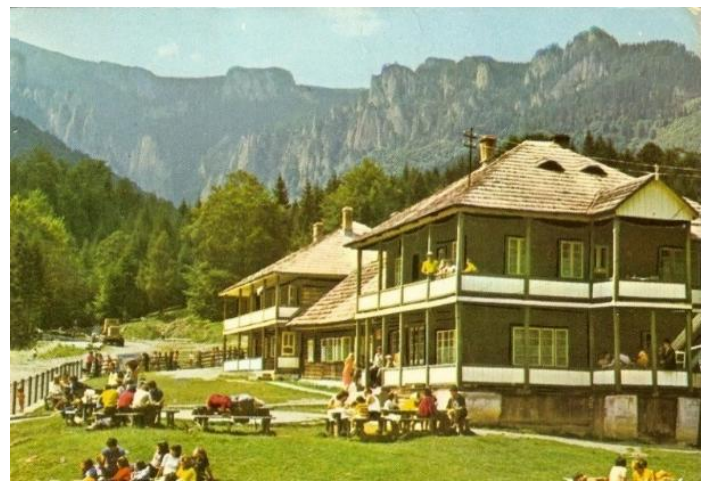

(f) Ceahlău massif panorama
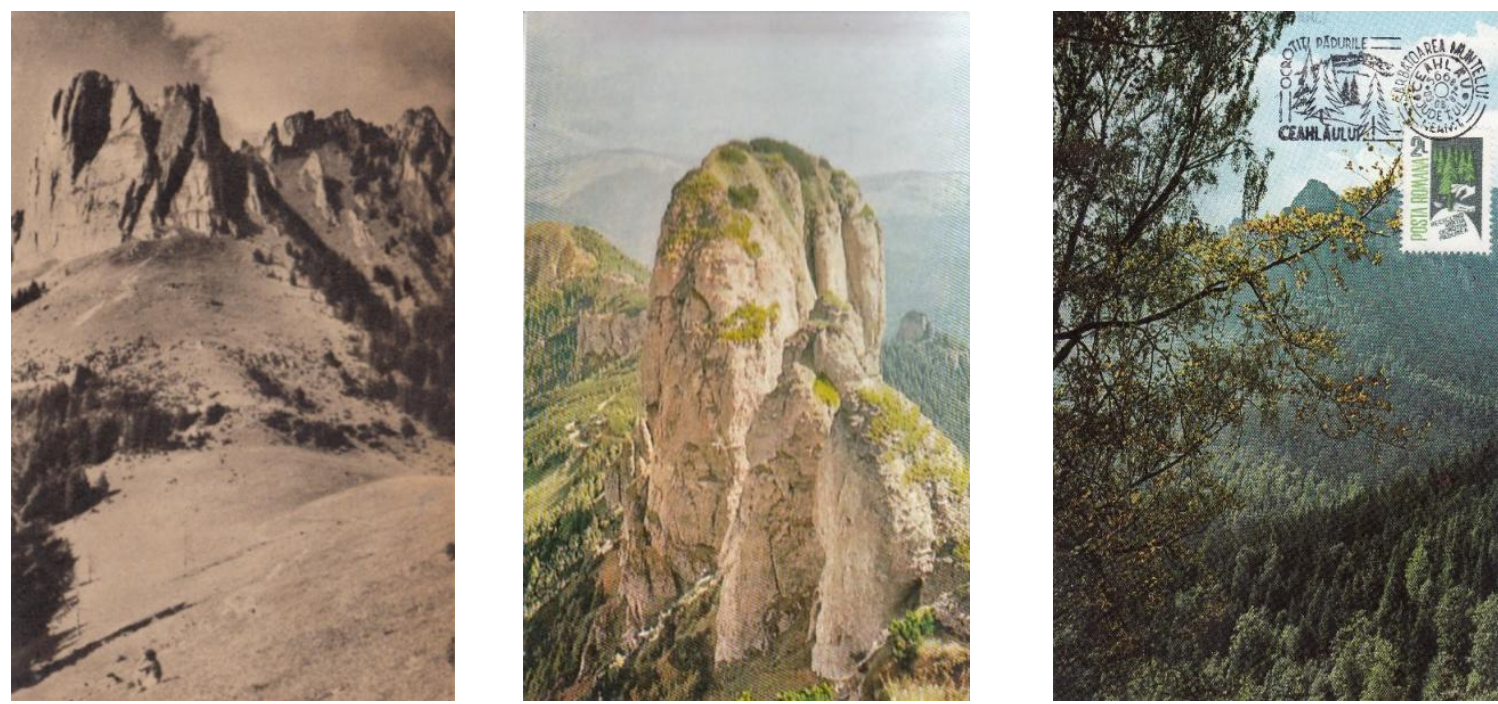

(g)-(i) Other aspects of the Ceahlău massif

Fig. 6. Illustrated postcards showing views from the Ceahlău National Park [39]-[47]

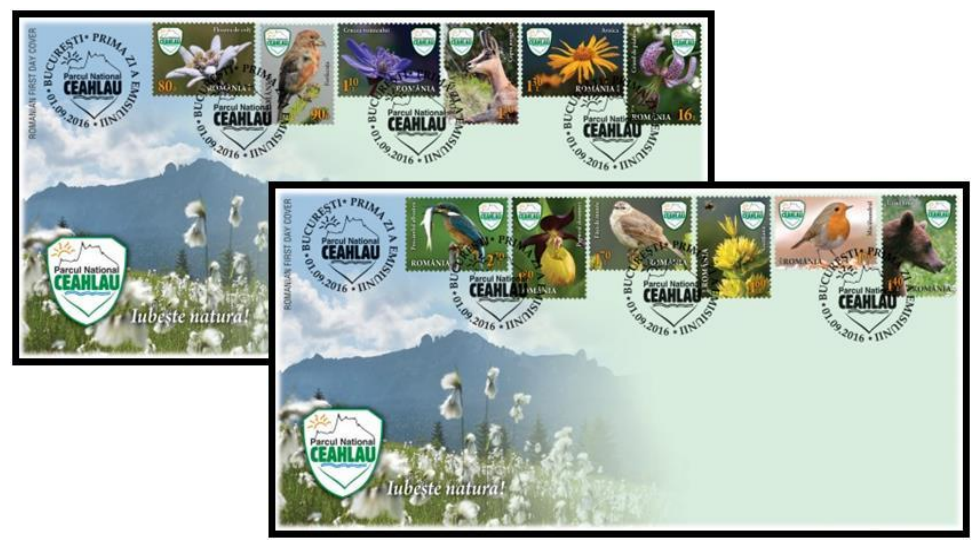

Fig. 7. "Love Nature! Ceahlău National Park" - two First-Day Covers (FDCs) [48],[51]

The stamp with the face value of 0.80 lei illustrates the edelweiss (Leontopodium alpinum), also known as the queen's flower or albumite. Declared as a monument of nature and protected by law, perennial herbaceous plants with low growth $(20 \mathrm{~cm})$, are the symbol of mountain hiking lovers, especially on calcareous cliffs with good sun exposure [48]. 
The Red crossbill (Loxia curvirostra), is found on the stamp with face value of 0.90 lei. This is a sedentary bird of the Fringillidae family, of medium size, which inhabits forested regions of Europe, central and northern Asia, it can also reache the North Africa. In our country it appears in the conifer forests of the Carpathian Mountains and is recognized by the thick beak whose curved jaws cross at the top, hence it's popular name.

Hepatica trans. Fuss appears on the stamp with the face value of 1.10 lei. As a rare endemic plant growing at high altitudes, the species has a special ecological and aesthetic value, being, by its beauty, a real delight for mountain hikers.

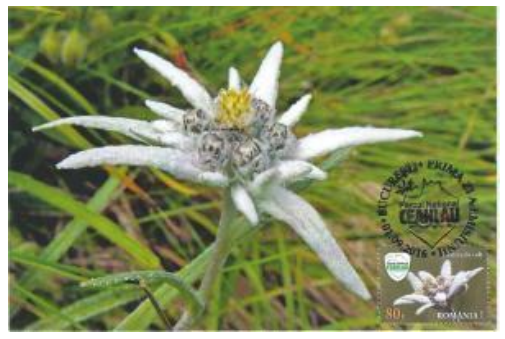

(a) Leontopodium alpinum

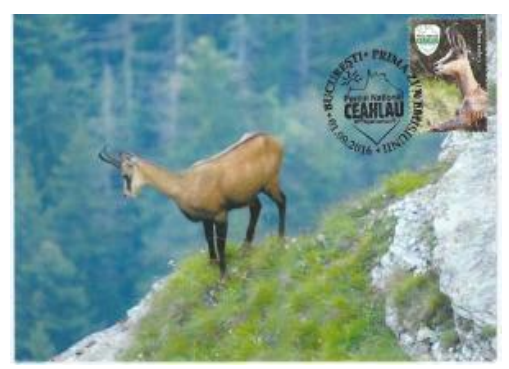

(d) Rupicapra rupicapra

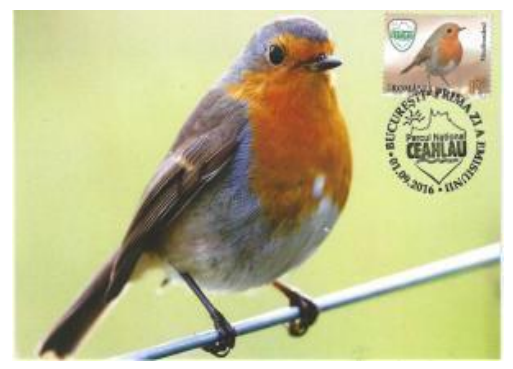

(g) Erithacus rubecula

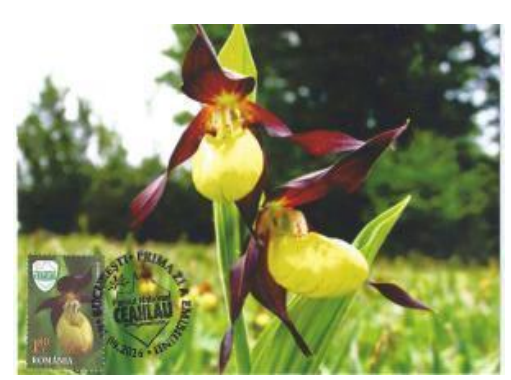

(j) Cypripedium calceolus

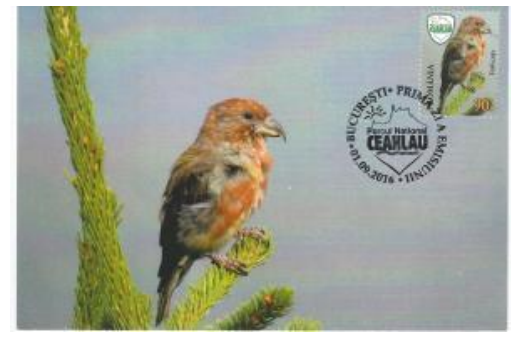

(b) Loxia curvirostra

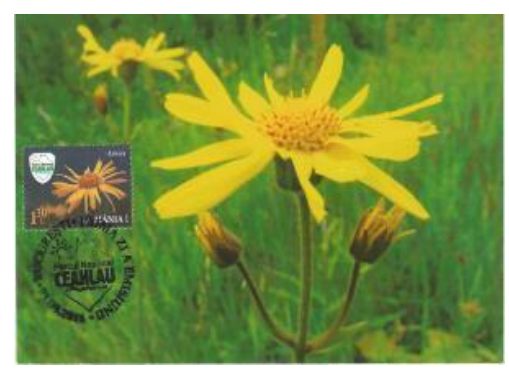

(e) Arnica montana

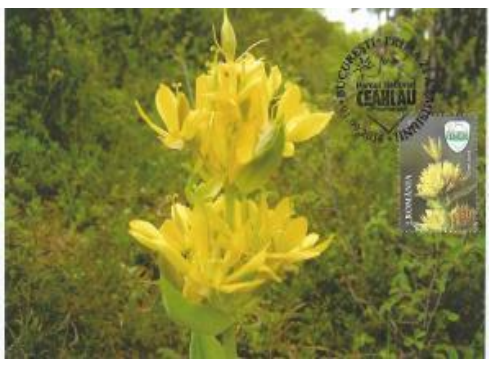

(h) Gentiana lutea

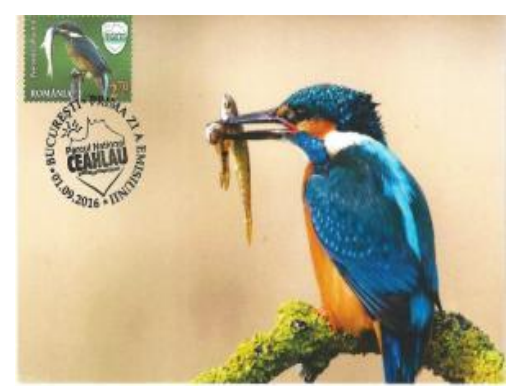

(k) Alcedo atthis

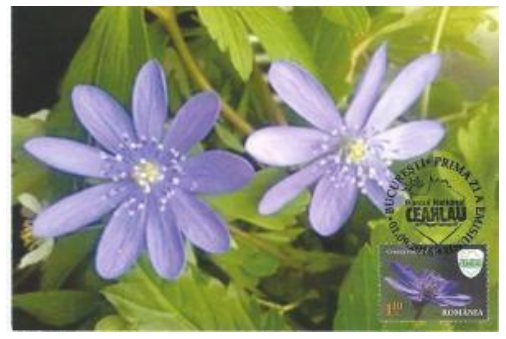

(c) Hepatica transsilvanica

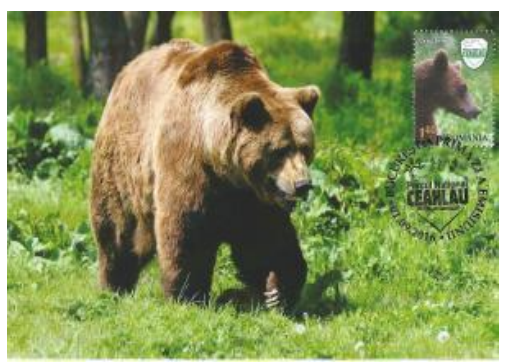

(f) Ursus arctos

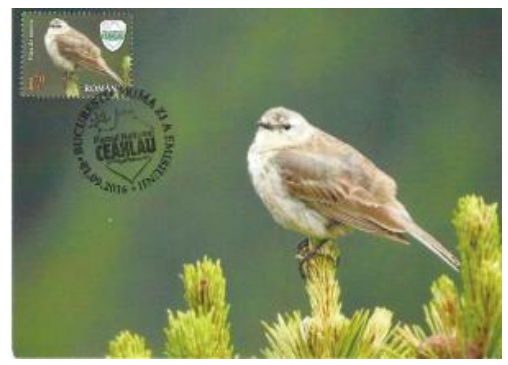

(i) Anthus spinoletta

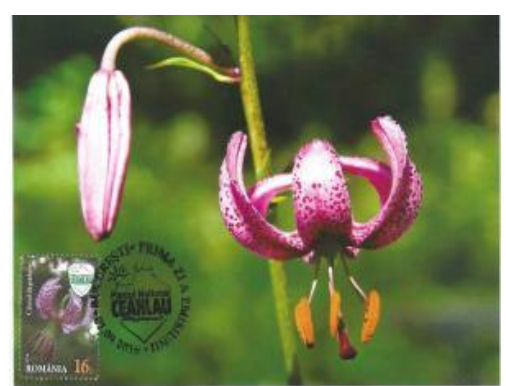

(I) Lilium martagon

Fig. 8. "Love nature! Ceahlău National Park" - maximum postcards [52] 
On a nominal value of 1.20 lei the chamois (Rupicapra rupicapra), one of the most valuable species belonging to the fauna of Romania, protected by law and considered a real pearl of the mountains, appears on the stamp with a nominal value of 1.20 lei. It can be found on the hillsides of the more rocky mountains, its movements being dictated by the need to find and consume food and the need to adapt to the climatic conditions.

Arnica (Arnica montana) is a perennial plant that grows in mountainous regions and has flowers similar to daisies - on the 1.30 lei stamp. The name comes from the Greek word "arnikos" - the skin of the lamb, but it is also known under the popular names of: the carriage of the woods, the sunbath, the carriage of the fairy. Located at over $1,000 \mathrm{~m}$ where it adorns the pastures with its golden-yellow flowers, this plant is the base of multiple mixtures, tinctures and extracts.

The brown bear (Ursus arctos), a longevive animal, who lives up to 30 years in the wild and even 20 years more in captivity, appears on the stamp with a face value of 1.40 lei. In Romania there is the largest number of brown bears in Europe, approx. 6,000 members [48]. This animal has been present in folklore, is remembered by $\mathrm{M}$. Eliade as the totem of some of the Dacian monk fighters, becoming a legendary figure, viewed with fear and admiring at the same time.

On the stamp with value of 1.50 lei is illustrated the European robin (Erithacus rubecula), an insectivorous bird encountered in Romania throughout the year. They nest in hollows, under banks or under trunks of fallen trees. In the summer, they reside in mountain forests, but in the winter, they descends to the plains, parks and gardens.

Great yellow gentian (Gentiana lutea) is represented on the stamp with the face value of 1.60 lei, being a herbaceous plant protected by

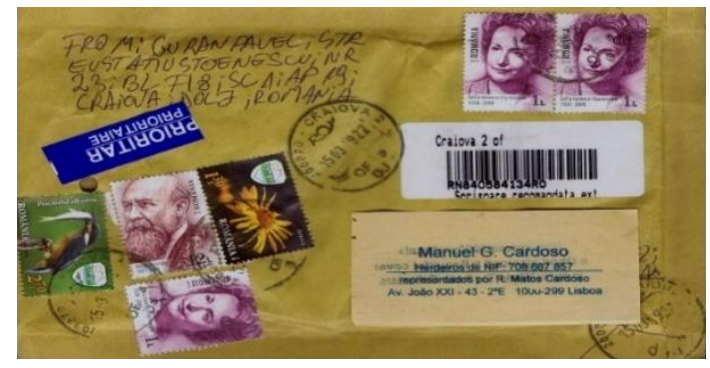

(a) law and declared a monument of nature. It grows in the spontaneous flora of Romania from the plain to the subalpine area.

The stamp with value of 1.70 lei illustrates the Water pipit (Anthus spinoletta), a bird that lives exclusively on the heights without forests of the Carpathians - in the meadows, the shingles or the learing of the forests where the vegetation is dense. It has a gray-washed color, with darker spots on the upper body. In the winter, like most birds migrate to southern lands, especially to northeastern Africa.

On the 1.80 lei stamp appears Lady's slipper orchid (Cypripedium calceolus), a very rare, orchid species. In Europe, the plant has become increasingly rare and has disappeared in some places; for this reason many countries now consider it a protected plant. In Romania, it has been protected since 1938 and, thanks to some organizations, "in vitro" propagation projects have been carried out to repopulate the areas [48].

The Eurasian Kingfisher (Alcedo atthis) is one of the most beautifully colored birds in our country. Blue-green on the back, reddish-brick below, on the abdomen and in front of the eyes, white on the goiter and the sides of the neck, it has short legs and tail, a large and strong beak. The bird lives on the shores of fast-flowing waters or those standing with clear water where there are fish.

The Turk's Cap Lily (Lilium martagon) is a species of plant in the order Liliales, the family Liliaceae that prefers mountainous areas in Central, Eastern, Southeastern, and Asia. In Romania, it is found in mountain meadows up to an altitude of $2400-2500 \mathrm{~m}$.

In Fig. 9 we chose to expose some of the circulations of the issue [53-58], to show that philately is ultimately a true ambassador of cultural and natural heritage.

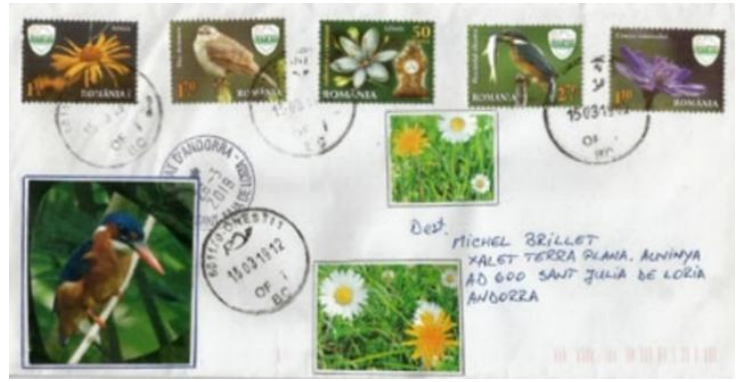

(b) 


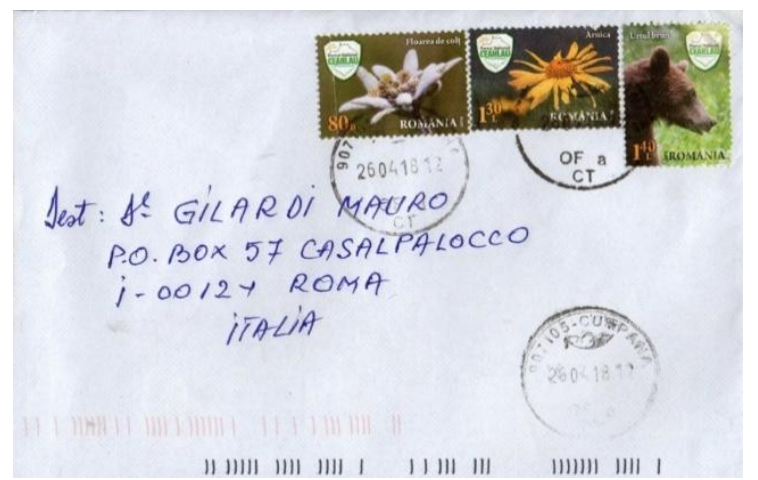

(c)

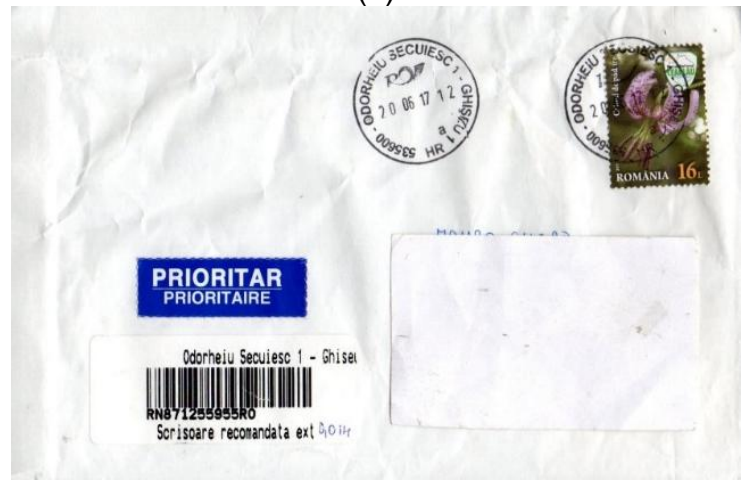

(e)

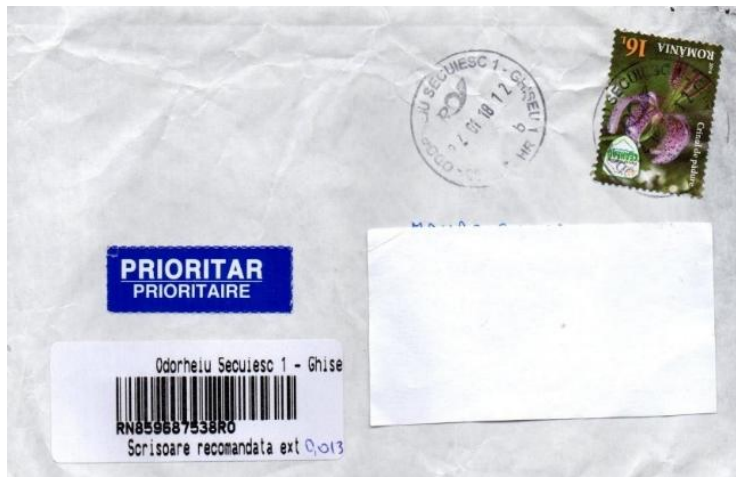

(d)

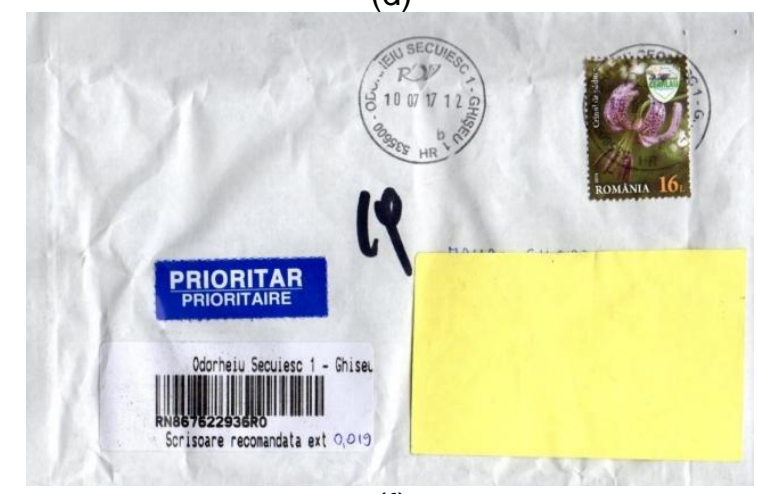

(f)

Fig. 9. "Love Nature! Ceahlău National Park" - circulated issues

\section{CONCLUSION}

In the paper, we bring to the fore the area of Ceahlău National Park both from an ecological point of view - by presenting the species of flora and fauna in the form of a short inventory, and philatelic point of view - by analyzing, describing and disseminating the main pieces identified in within philatelic content e-commerce sites. We were impressed by the way in which over time the Romanian postal administration decided to promote protected natural areas, the pieces identified being of a rare beauty, especially those made in 2009. We were also deeply impressed by the truly unique circulations of "Love Nature! Ceahlău National Park", although they are not spectacular in number. However, the implications of philately in the promotion of flora are noticeable (through the prism of the circulated pieces), most species being either unique or endangered and protected by law.

\section{COMPETING INTERESTS}

Authors have declared that no competing interests exist.

\section{REFERENCES}

1. Mesaroș M, Cioruța B, Coman M. Protected natural heritage on route from philosophy to environment engineering, Scientific Bulletin of North University Center of Baia Mare, Mining, Mineral Processing, Non-ferrous Metallurgy, Geology \& Environmental Engineering. Baia Mare. 2018; 32(1): 63-72.

2. Pop AL, Cioruța B, Coman M. Considerations regarding the implications of philately in ecological education, Scientific Bulletin of North University Center of Baia Mare, Mining, Mineral Processing, Non-ferrous Metallurgy, Geology \& Environmental Engineering. Baia Mare. 2017; 31(1): 57-62.

3. Cioruța B, Coman M. About the Contribution of Forest and Aquatic Ecosystems within Protected Areas to the Sustainable Development of Local Communities, Global Journal of Science Frontier Research: D Agriculture and Veterinary, 2020;20(8):12-18.

Available:https://journalofscience.org/index .php/GJSFR/article/view/2779 
4. Cioruta B, Coman M, Helindian AN. Contribution of forest and aquatic ecosystems within protected areas to the sustainable development of local communities, Magazine of Hydraulics, Pneumatics, Tribology, Ecology, Sensorics, Mechatronics. 2020;3(3):76-81. Available: https://hidraulica.fluidas.ro/wpcontent/uploads/2020/09/76-81.pdf

5. Cioruța B, Pop AL, Coman M, Lauran A. Implications of philately in promoting the protected natural areas (I): Ceahlău National Park, Scientific Bulletin of North University Center of Baia Mare, Series D, Mining, Mineral Processing, Non-ferrous Metallurgy, Geology and Environmental Engineering, Editura Utpress. 2018;32(1):87-96.

6. Pop AL, Cioruța B, Coman M. Implications of philately in promoting the protected natural areas (II): "Pețea Creek" Natural Reservation, Scientific Bulletin of North University Center of Baia Mare, Series D, Mining, Mineral Processing, Non-ferrous Metallurgy, Geology and Environmental Engineering, Baia Mare, Editura Utpress. 2018;32(2):43-52.

7. Cioruța B, Pop AL, Coman M. Implications of philately in promoting the protected natural areas (III): Cozia National Park, Asian Journal of Environment \& Ecology. 2020;13(3):1-8

Available:https://www.journalajee.com/inde x.php/AJEE/article/view/30181

8. Cioruța B, Pop AL, Coman M. Implications of philately in promoting the protected natural areas (IV): Domogled - Cerna Valley National Park, Asian Journal of Geographical Research. 2020;3(4):94-102. Available:

https://www.journalajgr.com/index.php/AJG R/article/view/30120

9. Cioruța B, Pop AL, Helindian AN, Coman M. Implications of philately in promoting the protected natural areas (V): Rodna Mountains National Park, Asian Journal of Geographical Research. 2020;3(4):81-93.

Available:https://www.journalajgr.com/inde x.php/AJGR/article/view/30119

10. Stanciu E, Florescu F. Protected areas in Romania, "Green Steps" Publishing House, Braşov, 2009. Available: https://propark.ro/images/uploads/file/man ual arii protejate_net.pdf. Romanian.

11. Scăiceanu C., Catalog of layout designers of Romanian postage stamps, Ed. Oscar Print, Bucureşti, Romanian; 2018.
12. Tudor Gh, Chiricheş C, Mermeze Gh, Catalog of Romanian postage stamps 1858-1989 (LP \#1-1232), Ed. AXA, Bucureşti, Romanian; 2017.

13. Tudor Gh, Chiricheş C, Mermeze Gh, Catalog of Romanian postage stamps 1990-2017 (LP \#1233-2135), Ed. AXA, Bucureşti, Romanian; 2017.

14. Available:https://colnect.com/ro/stamps/list/ country/177-

Rom\%C3\%A2nia/series/12547-

Environment_protection/year/1984

15. Available:www.stampworld.com/stamps/Ro mania/Postage-stamps/g4019

16. Available:www.delcampe.net/en_US/collec tibles/stamps/romania/fdc/1984-romaniaprotezione-della-natura-serie-cpl-su-fdc1021131484.html

17. Available:www.delcampe.net/en_US/collec tibles/stamps/environment-climateprotection/environement-protection-florafishes-mammals-birds-cover-fdc-1984romania-577956654.html

18. Available:www.delcampe.net/en US/collec tibles/stamps/unclassified-5/environmentalprotection-cover-fdc-fish-flower-deer-birds1984-romania-194733661.html

19. Available:www.delcampe.net/en US/collec tibles/stamps/romania/fdc/1984-protectingthe-environment-romania-mi-4031-4034fdc-181985921.html

20. Available:www.delcampe.net/en US/collec tibles/stamps/romania/fdc/1984-protectingthe-environment-romania-mi-4031-4034fdc-181985876.html

21. Available:http://romfilatelia.ro/magazin/pro dus/colectii-anuale/fauna-protejata-dinromania

22. Available:https://colnect.com/ro/stamps/list/ country/177-

Rom\%C3\%A2nia/series/49343-

Protected_Fauna_2019/year/2009

23. Available:www.stampworld.com/stamps/Ro mania/Postage-stamps/g6368

24. History of protected natural areas. National Directorate of Forests; 2020.

Accessed 12.07.2020.

Available:

www.rosilva.ro/articole/istoric arii naturale protejate _p_185.htm. Romanian.

25. Law no. $5 / 2000$ on the approval of the National Spatial Planning Plan - Section III - protected areas.

Available:

www.cdep.ro/pls/legis/legis_pck.htp_act_te $x t$ ?idt=22636. Romanian 
26. Decision no. 230 on the delimitation of biosphere reserves, national parks and natural parks and the establishment of their administrations; 2003.

Available: www.legex.ro/Hotararea-2302003-36800.aspx. Romanian.

27. Rațiu $A$, Legal regime of protected natural areas - practical aspects, Brașov; 2017.

Available:www.juridice.ro/wpcontent/uploads/2016/11/Regimul-juridical-ANP-aspecte-practice_Antoanela.pdf. Romanian.

28. Government Emergency Ordinance no. $57 / 2007$ on the regime of protected natural areas, conservation of natural habitats, wild flora and fauna, MO 442/2007

29. Ceahlău National Park.

Available:www.ceahlaupark.ro

30. Available:www.delcampe.net/en_US/collec tibles/postcards/romania/cpa-ceahlaumassif-mountains-poiana-teiului-bridge1011726860.html

31. Available:www.delcampe.net/en_US/collec tibles/postcards/romania/cpa-ak-vedereamontelui-ceahlau-din-jud-neamt-romania502911-814673941.html

32. Available:www.delcampe.net/en_US/collec tibles/postcards/romania/cpa-ceahlaumountain-panorama-659781361.html

33. Available:www.delcampe.net/en_US/collec tibles/postcards/romania/cpa-ceahlaumassif-mountains-toaca-peak1011726920.html

34. Available:www.delcampe.net/en_US/collec tibles/postcards/romania/masivul-ceahlauzori-de-zi-829556423.html

35. Available:www.delcampe.net/en_US/collec tibles/postcards/romania/cpa-ceahlaumassif-mountains-partial-panoramadetunata-peak-1011726890.html

36. Available:www.delcampe.net/en_US/collec tibles/postcards/romania/cpa-ceahlaumassif-mountains-partial-panorama1011726869.html

37. Available:www.delcampe.net/en_US/collec tibles/postcards/romania/cpa-ceahlaumassif-mountains-partial-panorama1011726866.html

38. Available:www.delcampe.net/en_US/collec tibles/postcards/romania/cpsm-roumaniele-massif-ceahlau-d3-90-251999846.html

39. Available:www.delcampe.net/en_US/collec tibles/postcards/romania/cpa-ceahlau- massif-mountains-partial-panorama-piatrasura-peak-1011726893.html

40. Available:www.delcampe.net/en_US/collec tibles/postcards/romania/cpa-ceahlaumassif-mountains-rocks-1011726911.html

41. Available:www.delcampe.net/en_US/collec tibles/postcards/romania/cpa-ceahlaumassif-mountains-landscape1011726863.html

42. Available:www.delcampe.net/en_US/collec tibles/postcards/romania/cpa-ceahlaumassif-mountains-partial-panoramadetunata-peak-1011726887.html

43. Available:www.delcampe.net/en_US/collec tibles/postcards/romania/romaniapostcard-stationery-code-3276-76ceahlau-mountain-7-november-cottageused-1976-731174414.html

44. Available:www.delcampe.net/en_US/collec tibles/postcards/romania/romaniapostcard-stationery-code-1640-76-bicazchalet-izvorul-muresului-used-1976-thefeast-of-mount-ceahlau-675262735.html

45. Available:www.delcampe.net/en_US/collec tibles/postcards/romania/44741-ceahlaumassif-385195877.html

46. Available:www.delcampe.net/en_US/collec tibles/postcards/romania/cpa-ceahlaumassif-mountains-partial-panoramapanaghia-peak-1011726884.html

47. Available:www.delcampe.net/en_US/collec tibles/postcards/romania/masivul-ceahlaumassif-romania-tourism-card-100264003119.html

48. Available:http://romfilatelia.ro/magazin/pro dus/colectii-anuale/iubeste-natura-parculnational-ceahlau

49. Available:https://colnect.com/en/stamps/list /country/177-Romania/series/256760Love_Nature_Ceahlau_National_Park/year /2016

50. Available:www.stampworld.com/stamps/Ro mania/Postage-stamps/g7101

51. Available:www.delcampe.net/en_US/collec tibles/stamps/sciences/nature/romania2016-national-park-ceahlau-set-2-fdc960768122.html

52. Available:https://alexantonache.wordpress. com/2016/09/02/iubeste-natura-parculnational-ceahlau

53. Available:www.delcampe.net/en_US/collec tibles/stamps/birds/other/romania-craiovacity-faune-birds-flora-ceahlau-natural-parksofia-ionescu-ogrezeanu-celebriteesnicolae-lorga-sp7012-1057217838.html

54. Available:www.delcampe.net/en_US/collec tibles/stamps/romania-1948- 
republics/covers-documents-6/faune-floredu-parc-national-ceahlau-annee-2016-surlettre-adressee-andorra-avec-timbre-adate-arrivee-749812784.html

55. Available:www.delcampe.net/en_US/collec tibles/stamps/plants/other/romania-2018mailed-envelope-flora-fauna-ceahlaunational-park-edelweiss-arnica-montanabrown-bear-882247018.html

56. Available:www.delcampe.net/en US/collec tibles/stamps/plants/other/romania-2018front-of-cover-registered-ceahlau-national- park-flowers-lilium-martagon954125546.html

57. Available:www.delcampe.net/en_US/collec tibles/stamps/plants/other/romania-2017registered-letter-flowers-ceahlau-nationalpark-lilium-martagon-877924207.html

58. Available:www.delcampe.net/en_US/collec tibles/stamps/plants/other/romania-2017registered-envelope-flora-fauna-ceahlaunational-park-lilium-martagon-front-cover849667594.html

(C) 2021 Cioruța et al.; This is an Open Access article distributed under the terms of the Creative Commons Attribution License (http://creativecommons.org/licenses/by/4.0), which permits unrestricted use, distribution, and reproduction in any medium, provided the original work is properly cited.

Peer-review history:

The peer review history for this paper can be accessed here: http://www.sdiarticle4.com/review-history/67983 